\title{
DIGITAL TRANSFORMATION OF THE LOGISTICS OPERATIONS OF THE TRADE ENTERPRIZE "METIZNYK"
}

\author{
Los V. O., Ocheretin D. V., Borodina I. S.
}

Zaporizhzhia National University

Ukraine, 69000, Zaporizhzhia, Zhukovsky str., 66

vitalos.2704@gmail.com,odvisua@gmail.com, irina98borodina@gmail.com

ORCID 0000-0002-7932-5232, ORCID 0000-0001-6705-6381

Key words:

Logistics systems, transformation, logistics flows, information technologies, trade, warehousing logistics.
In the article possibilities of digital transformation of logistics systems for trading activities are obtained. It is noted that each digital technology opens up additional opportunities for participants of the logistics system, as well as creates certain threats. Attention is drawn to the construction of a critical digital infrastructure and the development of a common procedure for protecting shared digital platforms. The digital transformation of the transport and logistics sphere is one of the elements of the formation of the digital economy. The scientific and technical achievements are designed to solve various problems facing the modern economy, which is reflected in the global spread of digital technologies. The process of introducing of the digital technologies into the activities of organizations of the transport sector not only enhances their competitiveness, but also leads to the digitization of the country's economy as a whole. The logistics sphere is interconnected with various sectors of the economy and due to the provision of quality logistics services, it becomes possible to ensure the effective functioning of the entire economic system of the country.

The key business processes of trade enterprise "Metiznyk" are described, namely the process of sale and delivery of goods to end consumers. The main digital transformations of logistics operations are considered and the volumes of sales of goods and services through websites are analyzed.

\section{ТРАНСФОРМАЦІЯ ЛОГІСТИЧНИХ ОПЕРАЦІЙ ТОРГОВОГО ПІДПРИСМСТВА «МЕТИЗНИК»}

\author{
Лось В. О., Очеретін Д. В., Бородіна І. С. \\ Запорізький національний університет \\ Украӥна, 69000, м. Запоріжжя, вул.. Жуковського 66
}

\section{Ключові слова:}

Логістичні системи, трансформація, логістичні потоки, інформаційні технології, сфера торгівлі, складська логістика.

\begin{abstract}
У статті розглянуто можливості цифрової трансформації логістичних систем торгової діяльності. Відзначено, що кожна цифрова технологія як відкриває перед учасниками логістичної системи додаткові можливості, так і створює певні загрози. Цифрова трансформація логістичної сфери є одним із елементів формування цифрової економіки. Сучасні досягнення науки i техніки покликані вирішувати різні завдання, що стоять перед сучасною економікою, що знаходить відображення в глобальному поширенні цифрових технологій. Процес впровадження цифрових технологій в діяльність організацій логістичної сфери не тільки сприяє підвищенню їх конкурентоспроможності, а й веде до цифровізації економіки країни в цілому. Логістична сфера взаємопов'язана $з$ різними галузями економіки і саме за рахунок надання якісних логістичних послуг стає можливим ефективне функціонування всієї економічної системи країни. В умовах формування цифрової економіки ефект від цифрової трансформації логістичної сфери забезпечує не тільки вдосконалення внутрішніх процесів логістичних організацій, але і виступає невід'ємним напрямком розвитку окремих регіонів і країни в цілому. Тож, у статті описано ключові бізнес-процеси торгового підприємства «Метизник», а саме процес продажу та доставки товарів кінцевим споживачам. Розглянуто основні цифрові трансформації логістичних операцій та проаналізовано обсяги продажів товарів і послуг через веб-сайти.
\end{abstract}

\section{Statement of the problem}

Today, in Ukraine and in the world, the logistics and trade sectors are amenable to digital transformation processes based on the introduction of elements of the digital economy both at the level of individual countries and on a global scale. In modern realities, the importance of logistics increases sharply, since it is this area that ensures the interaction of various spheres of material production (including the retail trade) related to the transportation of 26 resources and finished products. In the conditions of the formation of the digital economy, one of the factors ensuring the competitiveness of organizations is the implementation of the concept of digital transformation in order to intensify the activities of the logistics sector by increasing the efficiency of procurement and logistics of material resources and finished products. Thus, the issues of digital transformation of logistics processes are relevant and need to be addressed. 


\section{Analysis of recent studies and publications}

The research of the international market for services conducted by foreign and Ukrainian economists is devoted to the problems of the development of the logistics market. In particular Volunteer L. O. [1] during the analysis of information logistics of trade enterprises, it identifies specific business processes and information systems for process optimization. Rinkevich N.S.and Trushkina N.V. [2] considers the transformation of enterprises in the context of digitalization of logistics. In the article of Kachurovsky S.V. [3] examines e-commerce in logistics and its modern development trends based on innovative technologies, pays attention to the systematization of basic operations and areas of application of technologies. Despite the significant number of developments in this direction, the research of certain aspects of the digitalization process of logistics operations requires improvement, which determined the purpose of the research.

\section{Objectives of the article}

The purpose of the article is to research the features of the digitization process of logistics operations and substantiate the ways of their development.

\section{The main material of the research}

A logistics operation is a separate set of actions aimed at transforming the material flow. Examples of typical logistics operations are packaging, loading, transportation, warehousing, movement of raw materials and semifinished products in the manufacture of products, collection, storage and processing of information that corresponds to the material flow. The costs of the storage and processing of information make up a significant part of the logistics costs [1]. On the international market of logistics services, a number of characteristic trends can be distinguished, which are shown in Figure 1.

\begin{tabular}{|c|c|c|c|c|}
\hline \multirow[b]{2}{*}{$\downarrow$} & \multicolumn{3}{|c|}{ Trends of the development of the logistics market } & \multirow[b]{2}{*}{7} \\
\hline & $\nabla$ & 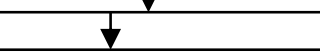 & 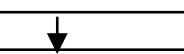 & \\
\hline $\begin{array}{l}\text { Globalization of } \\
\text { logistics companies }\end{array}$ & $\begin{array}{c}\text { The growing role } \\
\text { of information } \\
\text { technology }\end{array}$ & $\begin{array}{c}\text { Formation of branded } \\
\text { logistics networks }\end{array}$ & $\begin{array}{c}\text { Services } \\
\text { outsourcing }\end{array}$ & $\begin{array}{c}\text { The growing role } \\
\text { of marketing } \\
\text { strategies }\end{array}$ \\
\hline
\end{tabular}

Figure 1. Trends in the development of logistics operations

Analyzing Figure 1, it should be noted that the processes of globalization of logistics companies take place through mergers, acquisitions and business consolidation. As a result, there is a strengthening of the market positions of companies with a developed logistics network, which provide a range of services and a wide geography of business internationalization. Also, there is an increase in the role of information technology in the activities of companies, in particular, reliable telecommunication systems and software, automation of the supply chain. Despite the high degree of efficiency of in-house logistics chains, the most important trend in the logistics market has become outsourcing of services, which is called "contract logistics" in foreign practice. It should be noted that the marketing strategies of large logistics companies are dominated by a focus on creating a positive image of the company and the individual needs of the client, the use of client-oriented marketing.

Since logistics is part of the country's economic system in the form of an internal subsystem, it is characterized by digital transformations that are taking place in the Ukrainian economy (Fig. 2). With the transition of the Ukrainian economy to digital, an adequate transformation of logistics operations is required, including the logistics systems of trade activities.

The digital transformation of logistics processes in trading activities is aimed at minimizing overall logistics costs while maintaining a given quality of flow processes at all stages of the production and commercial business cycle. Transportation costs accompany all operations of the trading business, including the functions of searching and renting premises for the placement of goods; advertising and information, service functions, delivery of goods and other [2].

The digital logistics operations of trading activities are becoming part of the virtual marketplace. Virtual and augmented reality, which connects various infrastructure and service organizations, service providers, suppliers and other intermediaries, is transforming the way we interact with each other using software systems. The digital transformation of the logistics operations of trading activities necessitates the solution of the task of introducing end-to-end information technologies built on a single transport and logistics, production and trade infrastructure, which ensures the networking of business processes and favors the creation of "value chains for customers" [3]. The development of mechanisms for creating smart contracts, the search for new strategic directions for the innovative development of logistics systems for trading activities and the formation of supply chains for decision-making in business in order to optimize the impact of such functional parts as production, transportation, exchange and consumption are becoming relevant. 


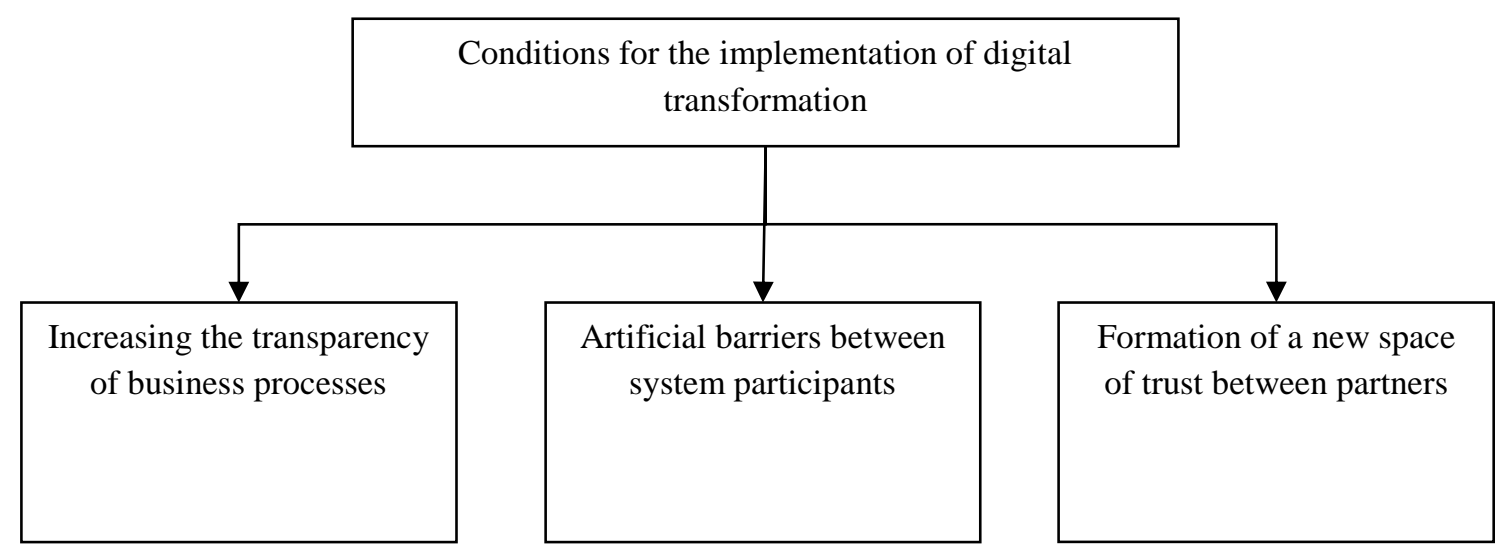

Figure 2. Conditions for the implementation of digital transformation of logistics systems

A high level of development of modern information technologies, the widespread use of which facilitates the provision of various services, has a great influence on the dynamic development of trade. These changes, together with the increasing turnover between the supplier and the client, affect the increasing role of logistics services in the modern market. Therefore, in recent years, an increase in the volume of logistics services has been observed in almost all countries, including Ukraine.

Let's analyze the volume of products sold using digital technologies, that is, using websites and a variety of mobile applications, in wholesale and retail trade (Table 1).

Table 1 - Internet e-commerce [4]

\begin{tabular}{|c|c|c|c|c|}
\hline \multirow{2}{*}{\multicolumn{2}{|c|}{ Index }} & \multicolumn{2}{|c|}{ Years } & \multirow{3}{*}{$\begin{array}{c}\text { Change index in } \\
2019 \text { relative to } \\
2018 \\
-24427499,9\end{array}$} \\
\hline & & \multirow{2}{*}{$\begin{array}{c}2018 \\
128502264,3\end{array}$} & \multirow{2}{*}{$\begin{array}{c}2019 \\
104074764,4\end{array}$} & \\
\hline Volume of sold products & Thousand UAH. & & & \\
\hline $\begin{array}{l}\text { (goods, services) } \\
\text { through web sites and } \\
\text { application programs }\end{array}$ & $\begin{array}{l}\% \text { to the total volume } \\
\text { of products sold }\end{array}$ & 4,7 & 3,7 & -1 \\
\hline \multirow{2}{*}{$\begin{array}{l}\text { The number of enterprises that } \\
\text { received orders via the Internet } \\
\text { for the sale of goods and } \\
\text { services }\end{array}$} & units & 914 & 924 & +10 \\
\hline & $\begin{array}{l}\% \text { to the total volume } \\
\text { of enterprises }\end{array}$ & 7,5 & 7,4 & $-0,1$ \\
\hline \multirow{2}{*}{$\begin{array}{l}\text { The number of businesses that } \\
\text { have made purchases of goods } \\
\text { and services online }\end{array}$} & units & 2288 & 2404 & +116 \\
\hline & $\begin{array}{l}\% \text { to the total volume } \\
\text { of enterprises }\end{array}$ & 18,7 & 19,3 & $+0,6$ \\
\hline
\end{tabular}

The volume of products sold in 2019 decreased by $1 \%$ or by 24427499.9 thousand UAH. Compared to the previous 2018, the number of enterprises that received orders for the sale of goods and services via the Internet decreased by $0.1 \%$. There is an increase in the number of enterprises that made the purchase of goods and ordering services via the Internet. The number of this orders increased by 116 units, which is $0.6 \%$. Thus, we can state the fact that an increasing number of Ukrainian enterprises use various information technologies in their activities. The trade enterprise |"Metiznyk", which sells non-food products, is not an exception. The enterprise management is trying to find reserves to reduce the costs of organizing the main activity of a trading company and reduce logistics costs is an important direction of such savings. One of the main places in the system of business processes of a trade enterprise is warehouse accounting, since in most cases the functional areas of logistics begin and end with warehouses [5].

Within the framework of the concept of digital transformation of the economy, trade enterprise "Metiznyk" uses information technologies and Internet means in its activities, namely online trade, which is carried out using its own website and social networks (Figure 3). 


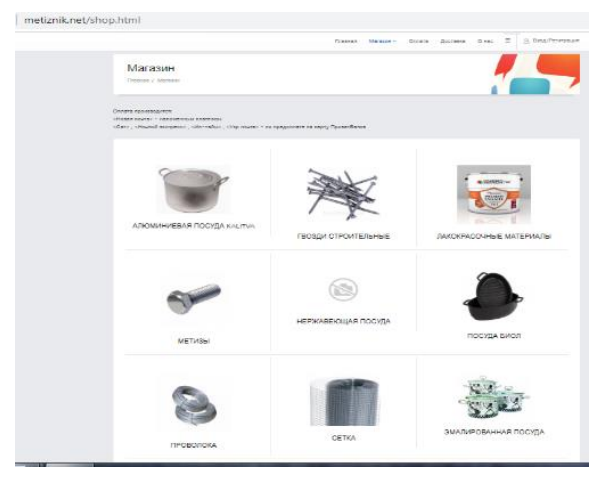

a)page of the web site

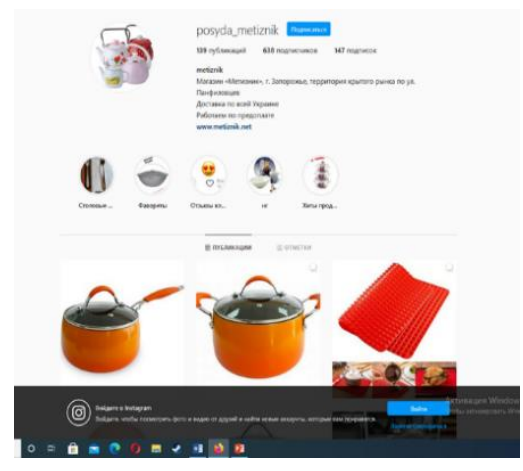

b) page in Instagram

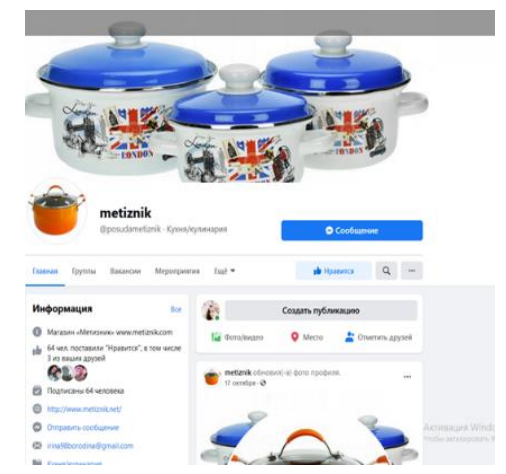

c) page in Facebook

Figure 3. Organization of online trading on the Internet by trade enterprise "Metiznyk"

Orders are sent to the website of the trade enterprise using a virtual basket. The account manager processes the application, contacts the client to confirm it and clarify the data. Then the manager transfers the order to the warehouse, from where the goods are sent to the customer using delivery services. When performing online trade, the company sends goods to customers from its own warehouse and in cases where the goods are out of stock, it uses a drop shipping scheme. The process of working with orders is shown in detail in Figure 4.

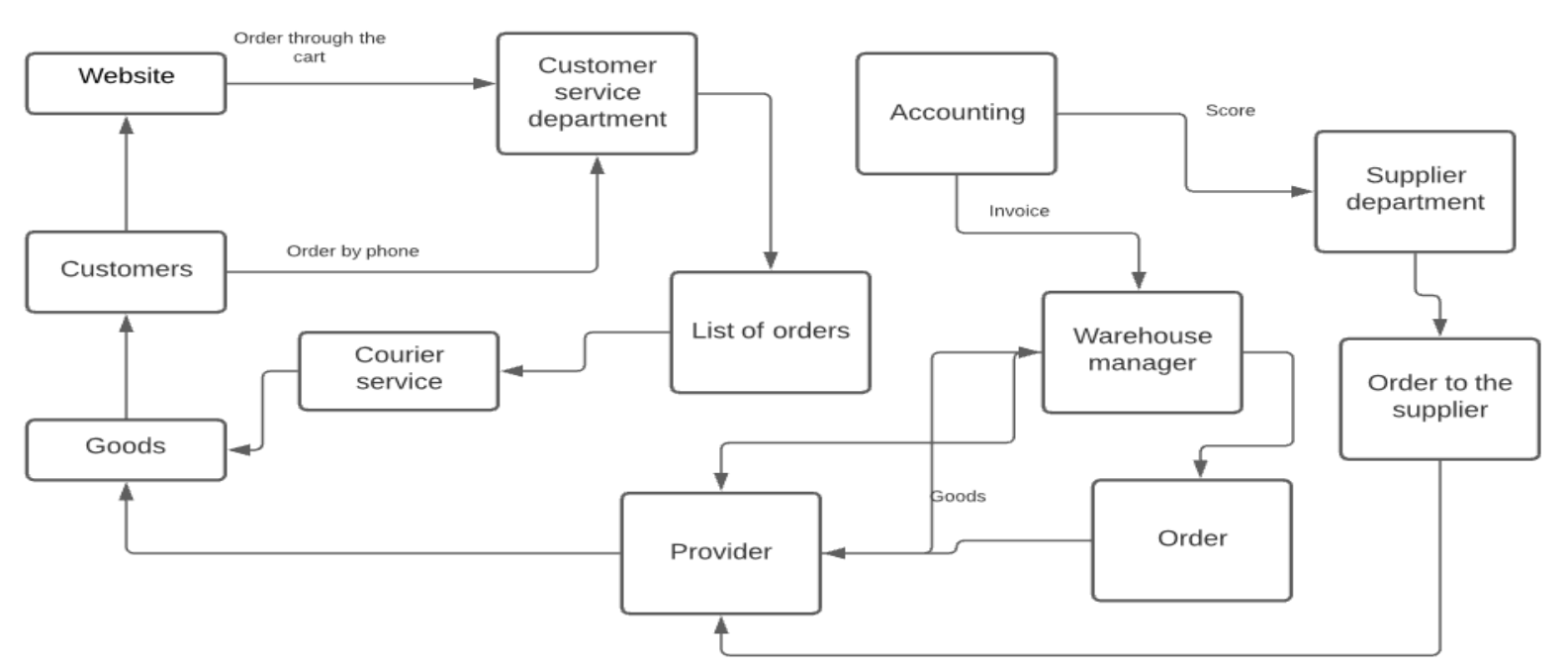

Figure 4. Business process of the trade enterprise "Metiznyk"

Today, the advantage of e-commerce can be considered the fact that it allows any person, enterprise or company to bring their business to the world market [7]. There is no time, holidays or weekends for e-commerce, since access to it are always open and this fact makes it easier for any business. E-commerce allows the client to choose a cheaper, but at the same time, high-quality product, however, the trading platform is not limited to this, since the client can get acquainted not only with the price and quality of the product, but also with the country of origin. At the same time, the human presence is completely excluded, that is, each buyer does not depend on the mood of sales representatives and various consultants and thus can sufficiently concentrate his attention on the main thing: the guarantee, price and quality of the goods in general. Thus, e-commerce makes it possible to perform such actions without leaving your home, which is very convenient these days.
Thus, we can conclude that currently the logistics sector is going through a process of digital transformation based on the introduction of digital technologies in all aspects of the activities of logistics organizations. In order to intensify digital transformation, organizations in this area need to carry out the process of optimizing the productivity of their activities based on monitoring the information available in their own databases, as well as with the help of attracted specialists in the field of digital transformation.

Organizations of the logistics sector, in order to support and improve their competitiveness, need to analyze existing business processes, assess the need for innovations and start implementing the digital transformation process both through the introduction of modern technological advances in science and technology, usage improved human resources, management systems corporate culture and other areas of the organization.

\section{References}

1. Volunteer, L. O. (2018) Informatsijna lohistyka biznes-struktur malykh pidpryiemstv [Information logistics of business structures of small enterprises]. Prychornomors'ki ekonomichni studii - Black Sea Economic Studies, 34, 198-202 [in Ukrainian]. 
2. Rinkevich, N. S., \& Trushkina, N. V. (2019) Tsyfrovva lohistyka iak instrument diial'nosti transportno-lohistychnykh kompanij v umovakh didzhytalizatsii [Digital logistics as a tool for transport and logistics companies in the context of digitalization]. Mizhnarodni vidnosyny Seriia "Ekonomichni nauky" - International Relations Series "Economic Sciences", 1(20), 66-68 [in Ukrainian].

3. Kachurovsky, S. V. (2018) Suchasni trendy E-COMMERCE v lohistytsi [Current trends of E-COMMERCE in logistics]. Visnyk Natsional'noho universytetu "L'vivs'kapolitekhnika" "Lohistyka" - Bulletin of the National University "Lviv Polytechnic" "Logistics", 892, 100-105 [in Ukrainian].

4. Ofitsijnyj sajt Derzhavnoi sluzhby statystyky Ukrainy [Official site of the State Statistics Service of Ukraine]. Retrieved from http://www.ukrstat.gov.ua [in Ukrainian].

5. Ofitsijnyj sajt torhovoho pidpryiemstva «Metyznyk» [Official site of Metiznyk trade enterprise]. Retrieved from http://metiznik.net/shop.html [in Ukrainian].

6. Dropshypinh: iak oformyty vidnosyny [Dropshipping: how to formalize a relationship]. Retrieved from ttps://ips.ligazakon.net/document/reader/BZ011846 [in Ukrainian].

7. Patramanska, L.Yu. (2015) Elektronna komertsiia: perevahy ta nedoliky [E-commerce: advantages and disadvantages]. Efektyvna ekonomika - Efficient economy, Retrieved from http://www.economy.nayka.com.ua/?op=1\&z=4505 [in Ukrainian]. 